\title{
Trace elements in South America aerosol during 20th century inferred from a Nevado Illimani ice core, Eastern Bolivian Andes (6350 $\mathrm{m}$ asl)
}

\author{
A. Correia ${ }^{1,2}$, R. Freydier ${ }^{3}$, R. J. Delmas ${ }^{2}$, J. C. Simões $^{4}$, J.-D. Taupin ${ }^{5}$, B. Dupré ${ }^{3}$, and P. Artaxo ${ }^{1}$ \\ ${ }^{1}$ Institute of Physics, University of São Paulo, São Paulo, Brazil \\ ${ }^{2}$ LGGE, CNRS and Université Joseph Fourier, Grenoble, France \\ ${ }^{3}$ UMR5563, LMTG, CNRS and Université Paul Sabatier, Toulouse, France \\ ${ }^{4}$ Institute of Geosciences, Federal University of Rio Grande do Sul, Brazil \\ ${ }^{5}$ LGGE, IRD, Grenoble, France
}

Received: 31 January 2003 - Published in Atmos. Chem. Phys. Discuss.: 7 May 2003

Revised: 6 August 2003 - Accepted: 26 August 2003 - Published: 11 September 2003

\begin{abstract}
A $137 \mathrm{~m}$ ice core drilled in 1999 from Eastern Bolivian Andes at the summit of Nevado Illimani (16 $37^{\prime} \mathrm{S}$, $67^{\circ} 46^{\prime} \mathrm{W}, 6350 \mathrm{~m}$ asl) was analyzed at high temporal resolution, allowing a characterization of trace elements in Andean aerosol trapped in the ice during the 20th century. The upper $50 \mathrm{~m}$ of the ice core were dated by multi-proxy analysis of stable isotopes $\left(\delta^{18} \mathrm{O}\right.$ and $\left.\delta^{2} \mathrm{H}\right),{ }^{137} \mathrm{Cs}$ and $\mathrm{Ca}^{+2}$ content, electrical conductivity, and insoluble microparticle content, together with reference historical horizons from atmospheric nuclear tests and known volcanic eruptions. This $50 \mathrm{~m}$ section corresponds to a record of environmental variations spanning about 80 years from 1919 to 1999 . It was cut in 744 sub-samples under laminar flow in a clean bench, which were analyzed by Ion Chromatography for major ionic concentration, by a particle counter for insoluble aerosol content, and by Inductively Coupled Plasma Mass Spectrometry (ICP-MS) for the concentration of 45 chemical species from $\mathrm{Li}$ to U. This paper focuses on results of trace element concentrations measured by ICP-MS. The high temporal resolution used in the analyses allowed classifying samples as belonging to dry or wet seasons. During wet season elemental concentrations are low and samples show high crustal enrichment factors. During dry seasons the situation is opposite, with high elemental concentrations and low crustal enrichments. For example, with salt lakes as main sources in the region, average Li concentration during the 20th century is 0.035 and $0.90 \mathrm{ng} \mathrm{g}^{-1}$ for wet and dry seasons, respectively. Illimani average seasonal concentration ranges cover the spectrum of elemental concentration measurements at another Andean ice core site (Sajama) for most soil-related elements. Regional crustal dust load in the deposits was
\end{abstract}

Correspondence to: A. Correia

(acorreia@if.usp.br) found to be overwhelming during dry season, obfuscating the contribution of biomass burning material. Marked temporal trends from the onset of 20th century to more recent years were identified for the concentrations of several trace species of anthropic origin, especially for $\mathrm{Cu}, \mathrm{As}, \mathrm{Zn}, \mathrm{Cd}$, $\mathrm{Co}, \mathrm{Ni}$ and $\mathrm{Cr}$. Among these elements, $\mathrm{Cu}$ shows average wet season crustal enrichment factors above $10^{3}$, while the others range between $10^{2}$ to about $5 \times 10^{2}$. $\mathrm{P}$ and $\mathrm{K}$ show moderate average wet season enrichment factors, suggesting an impact of natural biogenic emissions from the Amazon Basin. $\mathrm{Pb}$ has multiple anthropic sources in the region, from mining activities in the beginning of 20th century to automotive fuel after 1950s. From the large number of samples analyzed from Illimani, it was possible to derive an effective chemical characterization of the deposited background Andean soil dust aerosol during 20th century.

\section{Introduction}

Ice core records represent important tools for reconstructing past environmental conditions, from climatic variations to atmospheric chemistry. Several snow and ice cores from polar regions were studied in last decades, especially from Greenland and Antarctica (Wolff and Peel, 1985; Clausen and Langway, 1989; Lorius et al., 1989; Delmas, 1992). A limited number of Alpine ice cores studies have also been performed (Wagenbach, 1989). Pioneering work by Thompson and co-workers (e.g. Thompson, et al., 1985, 1988; Thompson, 2000) showed the importance of high-altitude tropical ice cores, with different features and challenges compared to polar ice cores. As with glaciochemical studies of snow and ice layers at other latitudes, it can be expected that chemical 
composition of snow impurities deposited at high elevation sites in the tropics reflects the free tropospheric aerosol composition on the regional scale. In general, tropical ice cores sites are closer to continental aerosol sources than polar ones, thus making their aerosol load much higher than in polar regions. Also moisture sources are typically closer to tropical ice cores, resulting in higher average snow accumulation rates and higher temporal resolution for the records representing environmental changes. Measured impurities may come from a variety of sources, either natural or anthropic in origin, with high spatial and temporal variability of the atmospheric concentrations and physicochemical climate-related characteristics. Most Andean ice core studies aimed at paleoclimate reconstructions. This is partly explained by the difficulties involved in the recovering of tropical ice cores under suitable conditions (no melting before analytical work, in particular) for glaciochemical analyses. The knowledge of the chemical composition of aerosol trapped by snow deposited in the Andes is limited to a few studies (e.g. Thompson et al., 1998), where the focus rests over a wide time scale covering several millennia or over a few elemental concentration profiles. This work addresses this issue, exploring a high temporal resolution (i.e. sub-seasonal) ice core record extracted from the Andes covering about 80 years during 20th century, which was analyzed for the concentration profiles of 45 chemical elements ranging from Li to U by Inductively Coupled Plasma-Mass Spectrometry (ICP-MS). The study of major ionic species by Ion Chromatography and the volcanic eruptions recorded at Illimani will be reported elsewhere (De Angelis et al., 2003a, 2003b).

\section{Ice core extraction and sample handling}

Two ice cores were drilled in 1999 by a French-Swiss team at the summit of Nevado Illimani (16 ${ }^{\circ} 37^{\prime} \mathrm{S}, 67^{\circ} 46^{\prime} \mathrm{W}$, $6350 \mathrm{~m}$ asl, about $40 \mathrm{~km}$ SE from La Paz). Figure 1 shows the location of the extraction site over Eastern Bolivian Andes (Cordillera Real). The two cores were separated by about $50 \mathrm{~m}$, and presented total lengths of $137 \mathrm{~m}$ (French core) and $139 \mathrm{~m}$ (Swiss core). Further details about glaciological features of the drilling site are given by Simões et al. (2003). This work discusses results of analyses performed on the French ice core.

Ice core sections drilled at Illimani, measuring about one meter in length and eight centimeters in diameter, were transported in cold conditions from the drilling site to $\mathrm{La} \mathrm{Paz}$ and then to cold chambers in European laboratories, being kept frozen at all times. This constraining procedure adopted for ice core handling makes the core suitable for a comprehensive glaciochemical study. In the cold chambers $\left(-15^{\circ} \mathrm{C}\right)$ of the Laboratoire de Glaciologie et Géophysique de l'Environnement (LGGE) in Grenoble, France, the ice core sections were weighed and had their lengths measured, then cut in halves which were saved for eventual future anal-
Table 1. ICP-MS setup conditions during analyses

\begin{tabular}{ll}
\hline Dwell time & $20 \mathrm{~ms}$ \\
Sweeps/Reading & 10 \\
Readings/Replicates & 1 \\
Replicates & 10 \\
Acquisition time & $1 \mathrm{~m} 57 \mathrm{~s}$ \\
Wash delay & $1 \mathrm{~m}$ \\
Flush delay & $1 \mathrm{~m} 40 \mathrm{~s}$ \\
Total scan time per sample & $4 \mathrm{~m} \mathrm{37 \textrm {s }}$ \\
Nebulizer gas flow & $0.86-0.881 \mathrm{~min}^{-1}$ \\
Auxiliary argon gas flow & $11 \mathrm{~min}^{-1}$ \\
Plasma gas flow & $151 \mathrm{~min}^{-1}$ \\
Power & $1200 \mathrm{~W}$ \\
Scanning mode & Peak hopping \\
\hline Tuning solution sensitivity (counts per second per ppb) \\
$\mathrm{Mg}$ & 94000 \\
Rh & 560000 \\
Pb & 700000 \\
\hline
\end{tabular}

ysis. The electrical conductivity in the remaining halves was measured along the profile. About $50 \mathrm{~m}$ of the ice core were cut in 744 sub-samples measuring from 6 to $10 \mathrm{~cm}$ in length. These sub-samples were decontaminated by removing their external layer with a stainless steel plane under a laminarflow clean bench. The external debris was used to measure ${ }^{137} \mathrm{Cs}$ content to check dating (Simões et al., 2003). Sub-samples consisting of the inner part of the core were then taken in double-sealed pre-cleaned plastic vessels to a class 100 clean room and allowed to melt at about $25^{\circ} \mathrm{C}$ in a laminar-flow bench. After melting, sub-samples were homogenized by gentle shaking and then split in three parts in pre-cleaned plastic vessels, for analyses of insoluble aerosol content (Simões et al., 2003), major ionic content by Ion Chromatography (De Angelis et al., 2003a) and trace element content by ICP-MS (this work). Sub-samples not being immediately analyzed were wrapped in moisture-proof tape (Parafilm M, Structure Probe) to minimize exchanges with the atmosphere, and then they were frozen in cold chambers in double-sealed plastic bags.

\subsection{Sample preparation and analysis by ICP-MS}

Sub-samples to be analyzed by ICP-MS were allowed to melt and acid-digested before analysis to assure complete dissolution of insoluble aerosol particles. These procedures were carried out at the Laboratoire des Mécanismes et Transferts en Géologie (LMTG), in Toulouse, France. Each sub-sample $(5-10 \mathrm{ml})$ was evaporated in pre-cleaned Teflon beakers in a laminar-flow bench at $50^{\circ} \mathrm{C}$. The dry residues were dissolved for $24 \mathrm{~h}$ at $50^{\circ} \mathrm{C}$ in a mixture of 1:1 $\mathrm{HF}: \mathrm{HNO}_{3}$. The acid solution was then evaporated and the dry residues were diluted in about $7 \mathrm{ml}$ milli-Q water with $2 \% \mathrm{HNO}_{3}$ (Sholkovitz et al., 1993; Freydier et al., 1998). Immediately before analysis a 


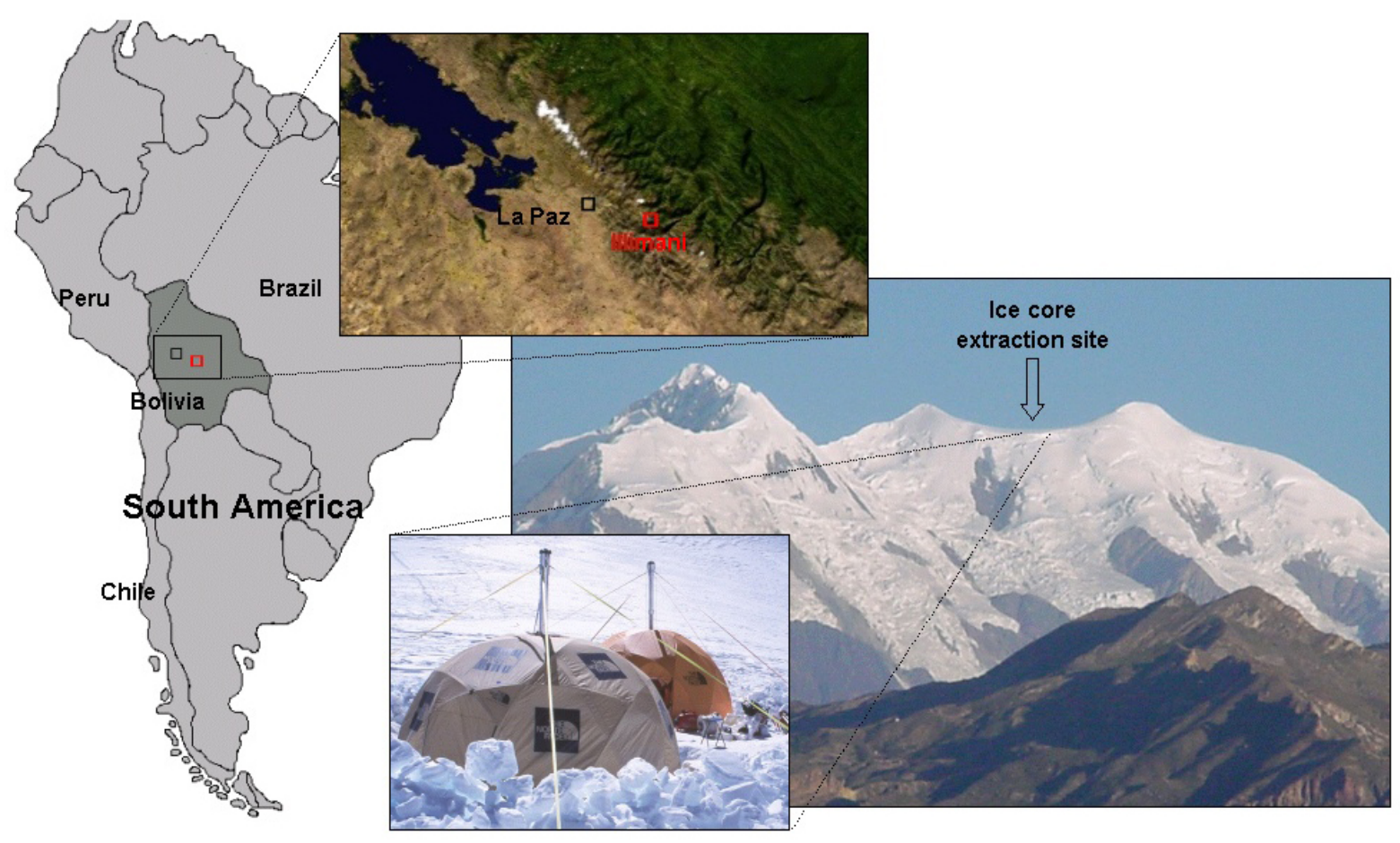

Fig. 1. Ice core extraction site location at Illimani, in Eastern Bolivian Andes, South America. Distance between La Paz and Illimani is about $40 \mathrm{~km}$.

known amount of a solution containing In and Re was added to each sample for calibration and elemental concentration determination by the internal standard with external calibration method.

Experimental conditions for the ICP-MS system (Elan 6000, Perkin Elmer) are reported in Table 1. Each measured elemental concentration is determined as the average of ten replicates, which in turn are averages of ten consecutive sweeps. The relative standard deviations of such sequence of measurements are typically under $5 \%$ for each elemental concentration. The sample introduction system is composed of a cyclonic spray chamber, a Meinhard nebulizer and a Knauer desolvation unit. This system is very useful for the analysis of low concentration natural waters because it increases the sensitivity by a factor of 5-10 relative to simple cross-flow nebulizers (Jakubowski et al., 1992). A fine aerosol cloud produced from the liquid sample enters the plasma torch and undergoes complete dissociation and ionization. The ions produced are separated according to their mass/charge ratios and detected using a discrete dynode electron multiplier. The reproducibility of the results in this system, using a riverine water standard (SLRS-4, National Research Council of Canada) during 11 months of analysis was between $7-13 \%$ for $\mathrm{Li}, \mathrm{Na}, \mathrm{Mg}, \mathrm{Al}, \mathrm{P}, \mathrm{K}, \mathrm{V}, \mathrm{Cr}, \mathrm{Co}, \mathrm{Ni}, \mathrm{Zn}$, $\mathrm{Ga}, \mathrm{As}, \mathrm{Zr}, \mathrm{Mo}, \mathrm{Cd}, \mathrm{Sb}$, Th, and U, and between 3-6\% for $\mathrm{Ti}, \mathrm{Mn}, \mathrm{Fe}, \mathrm{Rb}, \mathrm{Sr}, \mathrm{Y}, \mathrm{Ba}, \mathrm{La}, \mathrm{Ce}, \mathrm{Pr}, \mathrm{Nd}, \mathrm{Sm}, \mathrm{Yb}, \mathrm{Lu}$, and $\mathrm{Pb}$.

\section{Results and discussions}

\subsection{General considerations}

About $80 \%$ of annual precipitation at Illimani occurs during austral summer (DJF), having the Amazon Basin as the main moisture source (Vuille, 1999). Accordingly, prevailing wind pattern at $500 \mathrm{hPa}$ is from E-SE during summer and from WNW during winter. Precipitation during austral winter (JJA) also comes from Amazon, reaching the site as convective disturbances that break against the prevailing westerly flow (Grootes et al., 1989). As a consequence of this wind flow pattern, coupling of precipitation events to El Niño Southern Oscillation (ENSO) is weak over the Eastern Andes (Vuille et al., 2000).

The applied dating methodology of annual layer counting results in about 80 years (1919-1999) of environmental record for the top $50 \mathrm{~m}$ of the Illimani ice core. Seasonal variations of several chemical species made possible a yearby-year identification of annual layers over the whole profile. Dating was checked against historical horizons (Simões et al., 2003), such as major volcanic events (eruptions of Pinatubo, 1991, and Agung, 1963) and atmospheric nuclear tests (1962-63).

Quality assurance of sample handling and decontamination procedures was controlled with laboratory blanks. The average of two laboratory blanks per batch of 20-25 samples 
Table 2. Average blank levels and standard deviations for handling during ice core sub-sampling, ICP-MS sample preparation, and average instrumental ICP-MS detection limits ${ }^{a}$

\begin{tabular}{|c|c|c|c|}
\hline Element & $\begin{array}{l}\text { Average sub-sampling } \\
\text { (standard deviation) } \\
\left(10^{-12} \mathrm{~g} \mathrm{~g}^{-1}\right)\end{array}$ & $\begin{array}{l}\text { Average sample preparation } \\
\text { (standard deviation) } \\
\left(10^{-12} \mathrm{~g} \mathrm{~g}^{-1}\right)\end{array}$ & $\begin{array}{l}\text { Average instrumental detection limits } \\
\text { (standard deviation) } \\
\left(10^{-12} \mathrm{gg}^{-1}\right)\end{array}$ \\
\hline $\mathrm{Li}$ & $2.9(2.2)$ & $50(82)$ & $13(4.9)$ \\
\hline $\mathrm{Na}$ & n.d. & $1000(200)$ & $160(190)$ \\
\hline $\mathrm{Mg}$ & 87 (130) & $910(760)$ & $39(21)$ \\
\hline $\mathrm{Al}$ & n.d. & $1500(470)$ & $56(68)$ \\
\hline $\mathrm{P}$ & $510(140)$ & $400(180)$ & $450(120)$ \\
\hline $\mathrm{K}$ & n.d. & $1300(650)$ & $230(58)$ \\
\hline $\mathrm{Ca}$ & $8900(4900)$ & $7100(2600)$ & $6600(1200)$ \\
\hline $\mathrm{Sc}$ & $3.1(1.6)$ & $0.74(0.62)$ & $6.2(1.8)$ \\
\hline $\mathrm{Ti}$ & $4.1(2.0)$ & $190(99)$ & $23(5.3)$ \\
\hline $\mathrm{V}$ & $4.5(4.1)$ & $50(83)$ & $9.5(3.0)$ \\
\hline $\mathrm{Cr}$ & $69(21)$ & 79 (45) & $42(38)$ \\
\hline Mn & $6.6(0.85)$ & $14(7.9)$ & $5.2(0.82)$ \\
\hline $\mathrm{Fe}$ & $260(58)$ & $790(120)$ & $430(110)$ \\
\hline $\mathrm{Co}$ & $0.39(0.21)$ & $4.5(4.1)$ & $2.4(0.90)$ \\
\hline $\mathrm{Ni}$ & $2.1(0.67)$ & $89(100)$ & $37(18)$ \\
\hline $\mathrm{Cu}$ & n.d. & $280(480)$ & $120(210)$ \\
\hline $\mathrm{Zn}$ & $19(6.1)$ & $920(500)$ & $56(27)$ \\
\hline $\mathrm{Ga}$ & $0.14(0.010)$ & $1.5(2.3)$ & $1.7(0.44)$ \\
\hline $\mathrm{Ge}$ & $2.4(0.66)$ & $1.4(0.29)$ & $6.5(1.9)$ \\
\hline As & $7.7(13)$ & $160(210)$ & $28(9.0)$ \\
\hline $\mathrm{Rb}$ & $0.39(0.91)$ & $1.2(0.44)$ & $1.6(0.14)$ \\
\hline $\mathrm{Sr}$ & $4.6(2.7)$ & $13(3.7)$ & $1.5(0.51)$ \\
\hline $\mathrm{Y}$ & $0.019(0.0010)$ & $0.44(0.47)$ & $0.37(0.077)$ \\
\hline $\mathrm{Zr}$ & $0.042(0.014)$ & $4.3(1.8)$ & $5.0(2.2)$ \\
\hline $\mathrm{Nb}$ & $3.7(3.1)$ & $7.3(3.5)$ & $2.9(0.38)$ \\
\hline Mo & $2.7(2.0)$ & $5.9(0.83)$ & $25(40)$ \\
\hline $\mathrm{Pd}$ & $0.18(0.064)$ & $0.48(0.48)$ & $3.9(1.3)$ \\
\hline $\mathrm{Ag}$ & $1.9(1.6)$ & $2.7(1.1)$ & $2.3(0.12)$ \\
\hline $\mathrm{Cd}$ & n.d. & $1.2(0.33)$ & $3.2(1.3)$ \\
\hline $\operatorname{In}^{b}$ & - & - & $7.8(4.4)$ \\
\hline $\mathrm{Sb}$ & $0.55(0.068)$ & $3.1(1.65)$ & $1.9(0.47)$ \\
\hline Cs & $1.2(1.9)$ & $0.47(0.75)$ & $0.89(0.35)$ \\
\hline $\mathrm{Ba}$ & $1.6(0.50)$ & $290(200)$ & $5.2(2.6)$ \\
\hline $\mathrm{La}$ & n.d. & $1.3(0.41)$ & $0.57(0.37)$ \\
\hline $\mathrm{Ce}$ & n.d. & $1.7(0.61)$ & $0.66(0.39)$ \\
\hline $\operatorname{Pr}$ & $0.0088(0.0028)$ & $0.17(0.066)$ & $0.26(0.069)$ \\
\hline $\mathrm{Nd}$ & n.d. & $0.87(0.11)$ & $1.5(0.77)$ \\
\hline $\mathrm{Sm}$ & n.d. & $0.15(0.10)$ & $0.99(0.64)$ \\
\hline $\mathrm{Yb}$ & $0.018(0.0057)$ & $0.097(0.058)$ & $0.39(0.19)$ \\
\hline $\mathrm{Lu}$ & $0.021(0.0067)$ & $0.11(0.12)$ & $0.15(0.088)$ \\
\hline Hf & $0.079(0.013)$ & $1.9(2.8)$ & $1.8(1.5)$ \\
\hline $\mathrm{Ta}$ & $1.2(1.8)$ & $2.3(2.4)$ & $4.9(4.8)$ \\
\hline $\operatorname{Re}^{b}$ & - & - & $130(110)$ \\
\hline $\mathrm{Tl}$ & $0.73(1.0)$ & $0.75(0.43)$ & $1.1(0.85)$ \\
\hline $\mathrm{Pb}$ & n.d. & $14(1.8)$ & $2.1(0.75)$ \\
\hline $\mathrm{Th}$ & $0.88(1.3)$ & $1.1(1.2)$ & $1.5(1.3)$ \\
\hline $\mathrm{U}$ & $0.055(0.040)$ & $0.17(0.18)$ & $0.39(0.31)$ \\
\hline
\end{tabular}

${ }^{a}$ n.d.=not detected; bold values are below average detection limits;

$b$ elements used as internal standards. 


\section{Li concentration profile}
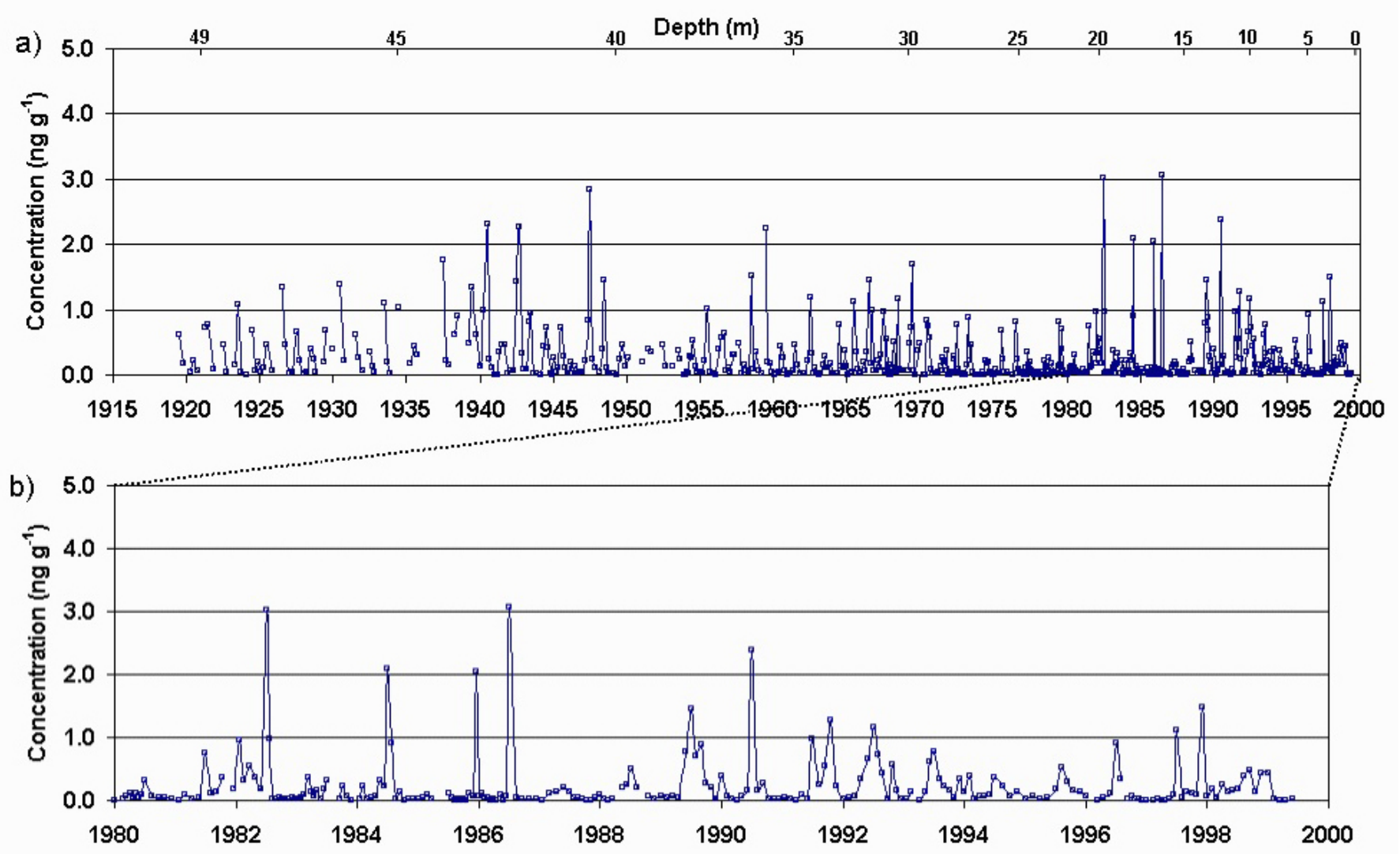

Fig. 2. Lithium concentration measured (a) for the full profile; (b) in the last 20 years of record. The strong seasonality is a common feature of most elemental concentrations measured.

was subtracted from sample elemental concentrations. For the ICP-MS analyses, specific batches of blanks were used to assess analytical quality and detection limits, calculated as three standard deviations of instrumental blanks (i.e. milli-Q water with $2 \% \mathrm{HNO}_{3}$ ). Detection limits were calculated dynamically along sample analyses, i.e., for each batch of about 10 samples, and only elemental concentrations above detection limits were used in all calculations in this work. Table 2 summarizes the average results of laboratory blanks for subsampling/handling of ice core sections and blanks of sample preparation for the ICP-MS analyses. For comparison, the average ICP-MS instrumental detection limits are listed in the same table. All concentrations in Table 2 are given with two significant figures in parts per trillion (i.e. $10^{-12} \mathrm{~g}$ of the element per gram of liquid sample). Several average blank concentration values are under the average detection limits for the analyses performed. Typical sample elemental concentrations lie in the range of hundreds to thousands of lab blank concentration levels and instrumental detection limits.

The ICP-MS analyses resulted in continuous concentration profiles for 45 chemical elements ranging from $\mathrm{Li}$ to $\mathrm{U}$ in the 744 samples. All elemental concentrations were de- termined in several hundreds of samples, although a few of them presented more limited numbers due to the low concentration levels involved (e.g. Pd, 218 samples, Ag, 234 samples, Ge, 377 samples and Ta, 389 samples). As an example of the results obtained, Fig. 2 shows the lithium elemental concentration profile measured at Illimani along 80 years from 1919 to 1999 . Figure 2a shows the full profile, while Fig. $2 b$ shows the last 20 years of record in detail. Important regional sources of lithium nearby Illimani site are salt lakes (e.g. Salar de Uyuni), which constitute the World's largest known Li reservoir (Risacher, 1992). Soil dust aerosol produced mechanically by wind friction mobilizes Li-rich particles and act as a regional source with variable strength depending on wind direction. As a consequence, average concentration ratio between $\mathrm{Li}$ and $\mathrm{Al}$ at Illimani, as measured by ICP-MS, is about three times greater than the mean soil composition determined by Bowen (1979).

One notices in Fig. 2 the strong seasonality evidenced in the Li profile, a common feature for most elemental concentrations measured. This seasonality is attributed to yearly precipitation regimes at the site, with low concentrations during the wet season (austral summer) and high concentrations 


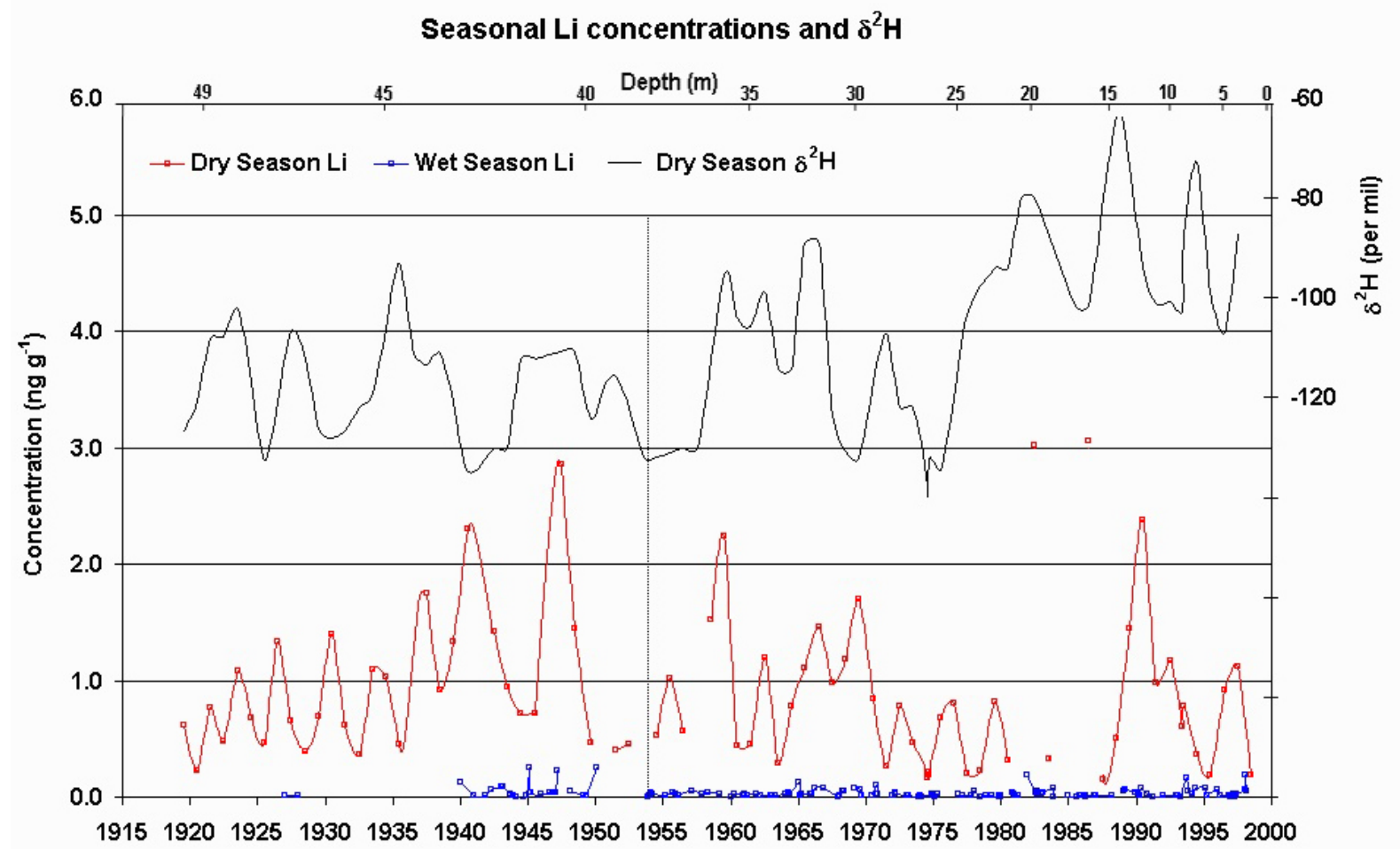

Fig. 3. Li concentration profiles measured for dry and wet seasons, and average dry season $\delta^{2} \mathrm{H}$. Dashed line explained in the main text.

during dry season (austral winter). Stable isotopes $\left(\delta^{18} \mathrm{O}\right.$ and $\delta^{2} \mathrm{H}$ ) are more depleted (more negative) for low concentration samples, which is consistent with a greater amount of water precipitating between the moisture source (the Amazon Basin) and the site during summer compared to winter, also in agreement with a model proposed by Grootes et al. (1989). The higher concentrations during the dry austral winter are a consequence of combined lower precipitation, easing aerosol mobilization due to dryness (De Angelis et al., 2003a), and increased snow sublimation due to availability of solar radiation.

Average annual net snow accumulation at the site is about $0.64 \mathrm{~m}$ of water (Simões et al., 2003), assuring the possibility of high temporal resolution studies compared to ice cores from polar sites, where snow accumulation can be as low as a few centimeters of water per year (Delmas, 1992). Studying the observed seasonality exemplified in Fig. 2 is only possible due to the high number of samples analyzed, which translates into high temporal resolution for the record. This is especially important for snow layers at the top of the core, where they are the least compressed by the weight of subsequent snowfall, and so the measured elemental concentration profiles have more than ten samples per year. As depth increases the deposited layers get progressively compressed, reducing the margin for high-resolution sampling, and thus the concentration profiles show about 4 samples per year by the depth of $50 \mathrm{~m}$. To the authors' best knowledge this is the first work studying such panoply of trace elements in ice cores with a continuous high temporal resolution, allowing seasonal segregation of samples to assess differences in atmospheric chemistry conditions.

For the recent years shown in Fig. 2b, there is no clear relationship between Li concentration and ENSO events like 1983, 1997 (warm phase) or 1988 (cold phase), although observed concentrations in 1983 and 1997 are very low. This is in accordance with the attributed Eastern major origin for moisture reaching the site, which implies a weak coupling to ENSO-related atmospheric processes (Vuille et al., 2000).

\subsection{Seasonal segregation of samples}

The detailed study of measured elemental concentration profiles, such as the Li example in Fig. 2, suggests a bimodallike behavior for the record, with successive periods of low concentration during the wet season followed by sharp increases in the dry season. In order to investigate these two states of the atmosphere, or weather regimes, each sample was classified as belonging to the "dry" or to the "wet" season. This classification was done by analyzing individually each sample and ascribing a classification category such as "dry", "wet" or "transition", according to dating and concentration levels observed for all measured elements. In this work only pure "dry" (76 cases) or "wet" samples (190 cases) are analyzed, avoiding more complex transition cases. In this classification scheme, one has forcefully fewer "dry" than 


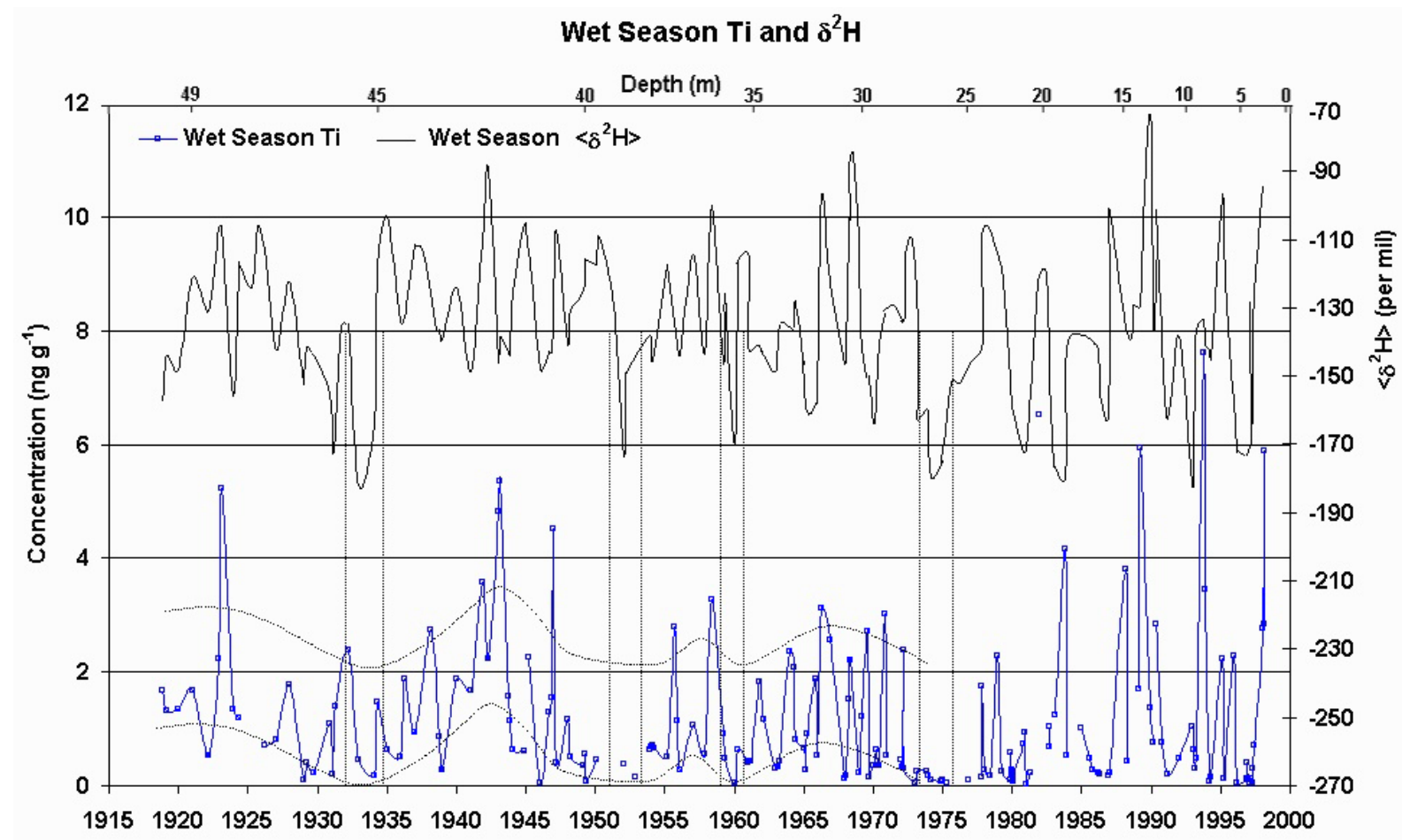

Fig. 4. Ti concentration profile for wet season samples, and average wet season $\delta^{2} \mathrm{H}$. Dashed lines explained in the main text.

"wet" samples, as they correspond to periods with less precipitation along the years.

Figure 3 shows the resulting dry and wet season concentration profiles for lithium. Wet season concentrations are very low compared to dry season ones, as expected from the discussion before. There is an oscillatory pattern for the concentrations during dry seasons in the beginning of 20th century, with a period ranging from 2 to 5 years, superimposed on an increasing trend. This is a common feature for most elements measured as well as for insoluble aerosol particles, and suggests a relationship to the total amount of solar radiation and precipitation reaching the site, modulating the observed concentrations. The pattern gets more complex after the dashed line by mid-50's, when the amplitude of dry season concentrations suddenly changes. Accordingly, there are distinct patterns for dry season $\delta^{2} \mathrm{H}$ in the two halves of the century, especially after 1955, as shown in Fig. 3 . The $\delta^{2} \mathrm{H}$ series represents measurements of $\delta^{2} \mathrm{H}$ made at the Laboratoire des Sciences du Climat et de l'Environnement (LSCE, Gif-sur-Yvette, France), averaged over the same dry season samples. The full analysis of stable isotopic content in Illimani ice core is given by Ramirez et al. (2003). Stable isotopes in the Andes are inversely related to temperature and precipitation history for short-term fluctuations, but remain positively related to temperature in long-term variations (Thompson, 2000). In this case the $\delta^{2} \mathrm{H}$ series in Fig. 3 indicates a shift towards warmer temperatures during wintertime (dry season), starting by mid-70s. This suggests a threat to the perspective of future research on Andean ice cores since low wintertime temperatures are key to preserve ice-sheet integrity.

Another important element, Ti, gives more clues about wet season concentrations that do not appear in Li profile, because of the low concentration values involved. Ti is a typical element associated with regional soil dust aerosol, and reproduces well the behavior of other elements from that same source. Figure 4 shows the wet season concentration profile for $\mathrm{Ti}$, together with the corresponding averages of wet season $\delta^{2} \mathrm{H}$. There are pronounced local Ti concentration minima around 1930, 1950, 1960 and 1975 assigned by vertical dashed lines, which coincide with minima in the $\delta^{2} \mathrm{H}$ series. For the most $\delta^{2} \mathrm{H}$ depleted wet seasons one has wetter conditions and largest amounts of precipitation, and then the measured concentrations get to their lowest values. The aforementioned years mark roughly five multi-year periods which can more easily be identified in the $\delta^{2} \mathrm{H}$ series in Fig. 4: from the beginning of the record up to $1930,1930-50,1950-60$, 1960-75, and then from 1975 to the end at 1999. For all but the last of these periods, concentration values during the wet season experience cycles during which they grow from a minimum value to a maximum value, and then start diminishing towards the next minimum, as roughly indicated by the curved dashed lines. The $\delta^{2} \mathrm{H}$ record after 1975 is different from the years before, but there is no clear trend as it was the case for dry seasons, implying roughly stable average temperatures during summer, but maybe with a different periodicity compared to the years before 1975 . 
Table 3. Elemental concentrations measured at Illimani and other locations

\begin{tabular}{|c|c|c|c|c|c|c|c|c|c|c|}
\hline \multirow[b]{2}{*}{ Period } & \multirow{2}{*}{$\begin{array}{l}\text { Antarctica }^{a} \\
1923-86\end{array}$} & \multicolumn{4}{|c|}{ Sajama $^{b}$} & \multicolumn{5}{|c|}{ Illimani $^{c}$} \\
\hline & & $22 \mathrm{Ka} \mathrm{BP}$ & 8 Ка ВР & ca.1650 & ca.1897 & $\begin{array}{l}\text { All samples, } \\
\text { 1919-99, A }\end{array}$ & $\begin{array}{l}\text { Dry season, } \\
1919-99, \text { D }\end{array}$ & $\begin{array}{l}\text { Wet season, } \\
1919-99, \text { W }\end{array}$ & $\begin{array}{l}\text { Dry season, } \\
1919-25, \mathrm{Db}\end{array}$ & $\begin{array}{l}\text { Wet season, } \\
1919-25, \mathrm{~Wb}\end{array}$ \\
\hline Element & \multicolumn{10}{|c|}{ Concentrations (ng g ${ }^{-1}$ ) } \\
\hline $\mathrm{Li}$ & & & & & & $0.251(668)$ & 0.900 & 0.0351 & 0.614 & \\
\hline $\mathrm{Na}$ & 60 & 63 & 74 & 165 & 118 & $71.4(733)$ & 249 & 12.4 & 165 & 7.53 \\
\hline $\mathrm{Mg}$ & & & & & & $33.6(730)$ & 133 & 4.28 & 88.5 & 3.93 \\
\hline $\mathrm{Al}$ & 1.7 & 205 & 240 & 540 & 373 & $233(735)$ & 965 & 18.1 & 701 & 25.6 \\
\hline $\mathrm{P}$ & & & & & & $6.19(663)$ & 21.3 & 1.53 & 12.3 & 1.22 \\
\hline K & & & & & & $101(728)$ & 388 & 14.3 & 270 & 11.7 \\
\hline $\mathrm{Ca}$ & & & & & & $86.6(721)$ & 255 & 23.9 & 151 & 19.0 \\
\hline $\mathrm{Sc}$ & & & & & & $0.0412(589)$ & 0.145 & 0.00607 & 0.104 & 0.00576 \\
\hline $\mathrm{Ti}$ & & 1.40 & 1.63 & 0.38 & 0.96 & $15.2(718)$ & 65.5 & 1.23 & 46.4 & 1.84 \\
\hline V & & 0.056 & 0.15 & 0.071 & 0.105 & $0.342(609)$ & 1.25 & 0.0331 & 0.897 & 0.0380 \\
\hline $\mathrm{Cr}$ & & 0.034 & 0.045 & 0.010 & 0.024 & $1.03(705)$ & 1.01 & 0.490 & 0.445 & 0.0837 \\
\hline $\mathrm{Mn}$ & & 2.460 & 3.525 & 5.160 & 3.620 & $3.39(740)$ & 12.0 & 0.586 & 7.75 & 0.304 \\
\hline $\mathrm{Fe}$ & & & & & & $112(737)$ & 480 & 11.6 & 331 & 13.6 \\
\hline Co & & 0.061 & 0.035 & 0.056 & 0.043 & $0.223(721)$ & 0.328 & 0.116 & 0.140 & 0.00824 \\
\hline $\mathrm{Ni}$ & & & & & & $0.654(596)$ & 0.465 & 0.419 & 0.170 & 0.0410 \\
\hline $\mathrm{Cu}$ & $0.0035^{a}$ & 0.090 & 0.240 & 0.058 & 0.147 & $2.77(600)$ & 2.31 & 2.44 & 0.890 & 0.405 \\
\hline $\mathrm{Zn}$ & 0.0015 & 0.266 & 0.224 & 0.205 & 0.380 & $3.03(661)$ & 4.41 & 2.47 & 1.99 & 0.599 \\
\hline $\mathrm{Ga}$ & & & & & & $0.0710(681)$ & 0.284 & 0.00594 & 0.218 & 0.00778 \\
\hline $\mathrm{Ge}$ & & & & & & $0.0120(377)$ & 0.0277 & 0.00261 & 0.0179 & 0.00142 \\
\hline As & & & & & & $0.623(661)$ & 1.53 & 0.334 & 0.872 & 0.171 \\
\hline $\mathrm{Rb}$ & & & & & & $0.435(737)$ & 1.86 & 0.0395 & 1.34 & 0.0474 \\
\hline $\mathrm{Sr}$ & & & & & & $1.31(710)$ & 4.76 & 0.146 & 3.06 & 0.123 \\
\hline $\mathrm{Y}$ & & & & & & $0.0669(730)$ & 0.284 & 0.00631 & 0.221 & 0.00800 \\
\hline $\mathrm{Zr}$ & & & & & & $0.386(686)$ & 1.57 & 0.0406 & 1.12 & 0.106 \\
\hline $\mathrm{Nb}$ & & & & & & $0.0558(478)$ & 0.181 & 0.00994 & 0.157 & 0.0120 \\
\hline Mo & & 0.0055 & 0.0144 & 0.0083 & 0.0105 & $0.0286(617)$ & 0.0474 & 0.0193 & 0.0208 & 0.00440 \\
\hline $\mathrm{Pd}$ & & 0.00032 & 0.00042 & 0.00028 & 0.00032 & $0.00247(218)$ & 0.00460 & 0.000935 & 0.00296 & \\
\hline $\mathrm{Ag}$ & & 0.00054 & 0.00066 & 0.00058 & 0.00171 & $0.00452(234)$ & 0.00723 & 0.00334 & 0.00616 & 0.00391 \\
\hline $\mathrm{Cd}$ & 0.0001 & 0.0018 & 0.0040 & 0.0060 & 0.0079 & $0.0127(636)$ & 0.0207 & 0.00837 & 0.00896 & 0.00184 \\
\hline $\mathrm{Sb}$ & & 0.0016 & 0.0025 & 0.0051 & 0.111 & $0.0525(701)$ & 0.146 & 0.0242 & 0.182 & 0.0350 \\
\hline Cs & & & & & & $0.0539(696)$ & 0.219 & 0.00569 & 0.166 & 0.00781 \\
\hline $\mathrm{Ba}$ & & 1.78 & 1.91 & 1.30 & 1.29 & $2.91(715)$ & 10.9 & 0.349 & 7.63 & 0.295 \\
\hline $\mathrm{La}$ & & & & & & $0.132(719)$ & 0.575 & 0.0108 & 0.404 & 0.0126 \\
\hline $\mathrm{Ce}$ & & & & & & $0.271(720)$ & 1.17 & 0.0227 & 0.823 & 0.0250 \\
\hline $\operatorname{Pr}$ & & & & & & $0.0303(719)$ & 0.131 & 0.00250 & 0.0905 & 0.00269 \\
\hline $\mathrm{Nd}$ & & & & & & $0.118(686)$ & 0.484 & 0.0106 & 0.336 & 0.00963 \\
\hline $\mathrm{Sm}$ & & & & & & $0.0231(641)$ & 0.0886 & 0.00221 & 0.0610 & 0.00187 \\
\hline $\mathrm{Yb}$ & & & & & & $0.00742(623)$ & 0.0275 & 0.000825 & 0.0215 & 0.000803 \\
\hline $\mathrm{Lu}$ & & & & & & $0.00131(510)$ & 0.00411 & 0.000190 & 0.00330 & 0.000167 \\
\hline $\mathrm{Hf}$ & & & & & & $0.0218(498)$ & 0.0671 & 0.00405 & 0.0538 & 0.00869 \\
\hline $\mathrm{Ta}$ & & & & & & $0.00698(389)$ & 0.0172 & 0.00231 & 0.0144 & 0.00303 \\
\hline $\mathrm{Tl}$ & & & & & & $0.00473(483)$ & 0.0129 & 0.000855 & 0.00964 & 0.000991 \\
\hline $\mathrm{Pb}$ & & 0.030 & 0.090 & 0.057 & 0.356 & $0.321(737)$ & 1.08 & 0.0820 & 0.974 & 0.0935 \\
\hline Th & & & & & & $0.0428(640)$ & 0.170 & 0.00427 & 0.106 & 0.00607 \\
\hline $\mathrm{U}$ & & 0.0044 & 0.0081 & 0.0027 & 0.0053 & $0.0117(654)$ & 0.0456 & 0.00116 & 0.0339 & 0.00151 \\
\hline
\end{tabular}

${ }^{a}$ Wolff et al., 1999. Snowpit at Coats Land, Antarctica, 77³4' S, 2522' W, $1420 \mathrm{~m}$ asl. Number of samples about 80 (read from graph). $\mathrm{Cu}$ average before 1970: $\sim 0.0025 \mathrm{ng} \mathrm{g}^{-1}$ (read from graph);

${ }^{b}$ Ferrari et al., 2001. One sample per date from Sajama ice core, Bolivia, $18^{\circ} 06^{\prime} \mathrm{S}, 68^{\circ} 53^{\prime} \mathrm{W}, 6542 \mathrm{~m}$ asl;

${ }^{c}$ This work. Number of samples used for the averages: number in parenthesis (all samples), 76 (dry season), 190 (wet season), 7 (dry season 1919-25), 9 (wet season 1919-25). 


\subsection{Comparison with other works}

Comparison of measured elemental concentrations with values registered in other locations is important, although difficult. Most elements presented here are often not measured in ice core related works, either for a matter of adequacy of the measuring system or due to a more restrictive scientific approach designed to address a specific question. Another problem is the statistical robustness of available data, since quite frequently one has few measured data points, thus compromising the significance or reliability of the results. In Table 3 averages of elemental concentrations in this work are compared to measurements at other locations in Antarctica (Wolff et al., 1999) and in the Western Andes (Ferrari et al., 2001). Samples from these sites were not acid-digested before analysis, which may be a problem for the detection of insoluble elements, especially in the case of heavy aerosolloaded Andean samples. For the site in Coats Land, Antarctica ( $200 \mathrm{~km}$ from sea shore), one has averages of about 80 samples (as read from graph) of elemental concentrations measured from a snowpit representing a time series from 1923 to 1986. In Western Andes the measurements were performed on four samples from an ice core extracted at Sajama ice cap, Bolivia (about $200 \mathrm{~km} \mathrm{SW}$ of Illimani), representing different ages before the 20th century. Although the Sajama ice core site is located in the Bolivian Andes, precipitation and weather regimes are quite different from the conditions at Illimani: while the main source of moisture reaching Illimani is located to its East (Amazon Basin, and ultimately, the Atlantic Ocean), Sajama is impacted by moisture coming from the Pacific Ocean. Also Sajama presents a lower average snow accumulation rate $\left(0.40 \mathrm{~m} \mathrm{H}_{2} \mathrm{O}\right.$ /year) (Ferrari et al., 2001) compared to Illimani $\left(0.64 \mathrm{~m} \mathrm{H}_{2} \mathrm{O}\right.$ /year) (Simões et al., 2003).

The elemental concentrations at Illimani were averaged following different methodologies in order to encompass diverse possibilities for comparison with the results in Table 3. First, a global average of all 744 samples was computed, corresponding to the time period from 1919 to 1999 (referred in the text as A). Then, the corresponding seasonal averages for the same period were computed using 76 samples for the dry seasons (marked as D) and 190 for the wet seasons (W). As discussed before, dry season samples give average upper range limits for the measured concentrations, while wet season averages correspond to lower range limits. Also, averages for dry and wet season concentrations (referred as Db and $\mathrm{Wb}$ ) were calculated for the years at the beginning of the record ( 7 and 9 samples respectively), from 1919 to 1925, to estimate elemental concentration ranges at the onset of the 20th century.

In Table 3 one notices that several elemental concentrations measured at Sajama ice cap are compatible with the values recorded at Illimani. For $\mathrm{Na}$, the range covered by $\mathrm{W}$ to $\mathrm{D}$ samples brackets the values measured for Sajama. Although this element is usually associated with sea salt aerosol, Fer- rari et al. (2001) show that crustal enrichment factors for this element are close to unity at Sajama, and it can be associated to soil dust. In Antarctica the measured $\mathrm{Na}$ is well within the range measured at Illimani and Sajama, but in this case the origin should be coastal sea salt aerosol, since the fraction of exposed soil and the overall aerosol loading are small compared to the Andean sites. This is also reflected in the low Al concentration recorded in Antarctica, compared to Illimani and Sajama. The concentration range defined by $\mathrm{W}$ to $\mathrm{D}$ averages at Illimani also encompasses the values at Sajama for Mn, Mo, Ba and U, especially when one considers the natural environmental variability expressed as the sample standard deviations (not shown) of the averages calculated for Illimani.

In general $\mathrm{Ti}, \mathrm{V}$ and $\mathrm{Cr}$ measured at Illimani are above the measured values at Sajama. This could be related to different sensitivities of each site to the impact of soil dust aerosol sources, but one may not preclude differences in sample preparation (acidic digestion) discussed before as a possible explanation, since partial ionization of insoluble aerosol particles may result in decreased or unstable measurements of concentrations for some elements (Freydier, 1997). In the case of $\mathrm{Cr}$, one notices at Illimani an increase of seasonal concentration ranges along 20th century, probably due to anthropogenic emissions, since this element shows an average wet season enrichment factor of about $10^{2}$ (cf. Fig. 5 discussion below).

For $\mathrm{Co}$, the concentration ranges $\mathrm{Wb}$ to $\mathrm{Db}$, from the beginning of the 20th century at Illimani explain the values recorded at Sajama. The Co average range $\mathrm{W}$ to $\mathrm{D}$ for the full record suggests a higher level of this element present in the atmosphere for the subsequent years. For $\mathrm{Pb}$ the situation is similar, with $\mathrm{Wb}$ to $\mathrm{Db}$ ranges covering the measurements at Sajama, but also W to D. Remarkably, both ranges are quite similar, i.e., the average ranges of $\mathrm{Pb}$ concentration between wet and dry seasons at the beginning of the century are close to the average for the whole record. This could be related to the impact of different sources along the record, like $\mathrm{Ag}$ mining (where $\mathrm{Pb}$ is rejected openly in the atmosphere) and $\mathrm{Pb}$ addition to automotive fuel in the second half of 20th century.

Cd measured at Sajama also corresponds to the range observed at Illimani at the beginning of the century ( $\mathrm{Wb}$ to $\mathrm{Db}$ ), but the average of all samples in the profile, $\mathrm{A}$, is about one order of magnitude greater than top $\mathrm{Db}$ values, evidencing the increase in $\mathrm{Cd}$ atmospheric concentrations along the century. This century-average is nearly two orders of magnitude greater than the average concentration in Antarctica for about the same period (1923-1986).

The Sajama sample dated ca. 1897 has Sb concentration considerably higher than the values measured at the same site for the other three samples. This value is within the $\mathrm{W}$ to $\mathrm{D}$ and $\mathrm{Wb}$ to $\mathrm{Db}$ concentration ranges measured at Illimani. The low Sb concentration values for the three oldest samples at Sajama may be due to a limited source strength over 


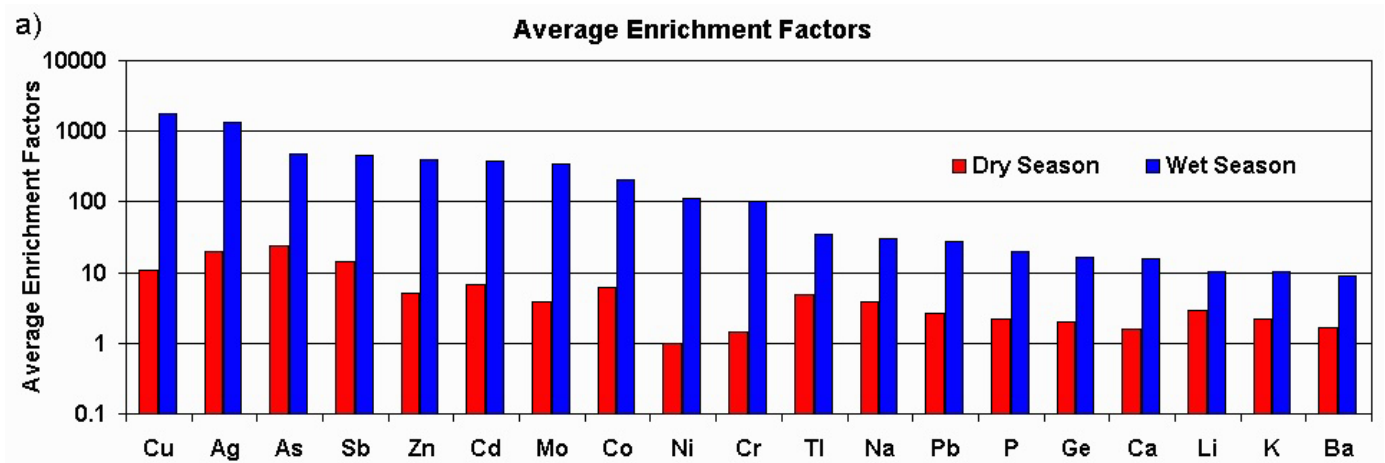

b)

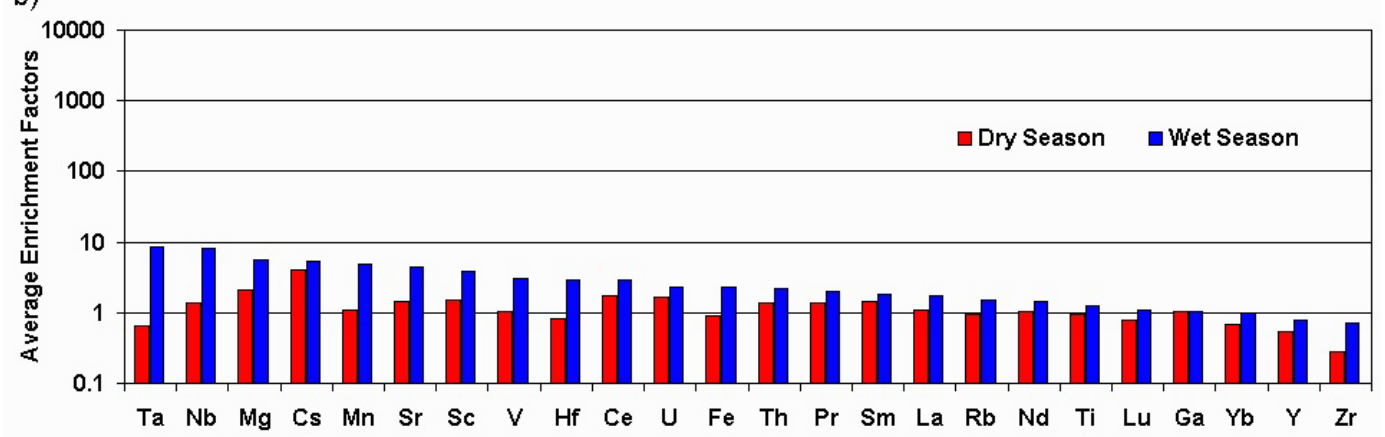

Fig. 5. Average enrichment factors for the measured elements during dry and wet seasons: (a) heavily and moderately enriched elements; (b) lightly enriched elements.

the site, which could indicate a growing impact trend over the Andes, but sample preparation methodology could also account for part of these differences.

The $\mathrm{Zn}$ average concentration in Antarctica is about 2000 times below $\mathrm{Zn}$ average for the whole record at Illimani, while average $\mathrm{Cu}$ concentration in Antarctica before the 1970 s is about three orders of magnitude below centuryaverage at Illimani. In the case of $\mathrm{Ag}, \mathrm{Pd}, \mathrm{Cu}$ and $\mathrm{Zn}$, the concentration values at Illimani are always higher than those registered at Sajama. This could be due to a greater impact of mining activities upon Illimani than Sajama. Notice that $\mathrm{Cu} \mathrm{D}$ and $\mathrm{W}$ averages are very similar, in accordance with a mining, rather non-seasonal, origin for this element. Further discussion on heavy metals measured at Illimani will be given elsewhere.

\subsection{Enrichment factors}

The concentration profiles for Li (Fig. 3) and Ti (Fig. 4) show general features of the record, which are echoed by most of the measured elements related to regional aerosol sources. An important tool used to estimate the contribution of other sources are enrichment factors, calculated from some reference source. Enrichment factors $(E F)$ were calculated using the conventional equation:

$$
E F=\frac{[X / \text { Ref }]_{\text {sample }}}{[X / \text { Ref }]_{\text {reference }}}
$$

where $X$ is the concentration of the element one wants to calculate the enrichment factor for, and Ref is the concentration of the reference element to be used. After a careful study of several possible choices, $\mathrm{Al}$ was assumed as the reference element for soil dust aerosol in this work.

Here the reference concentration ratios correspond to the average soil composition determined by Bowen (1979). This choice poses some difficulties, since there are fractionation processes occurring at the interface between the soil and the atmosphere when the aerosol is produced. Another disadvantage arises from the fact that one deals with the mean soil composition, which may be different from regional soil conditions, such as the presence of the Li-rich salars. Nonetheless, using this source allows other researchers to compare their results with the ones presented in this work, and so this procedure was adopted.

Figure 5 shows the averages of enrichment factors calculated for all the measured elements, for dry and wet seasons. While wet season elemental concentrations are lower than dry season concentrations, their enrichment factors are always more elevated for all measured elements. This indicates that during the dry winter season the aerosol reaching the site tends to be closer to soil dust, maybe because of enhanced production of regional aerosol due to soil dryness, while during wet summer the regional coarse soil dust aerosol is more efficiently removed by wet deposition processes than fine remotely-transported aerosol from other sources. Certainly 


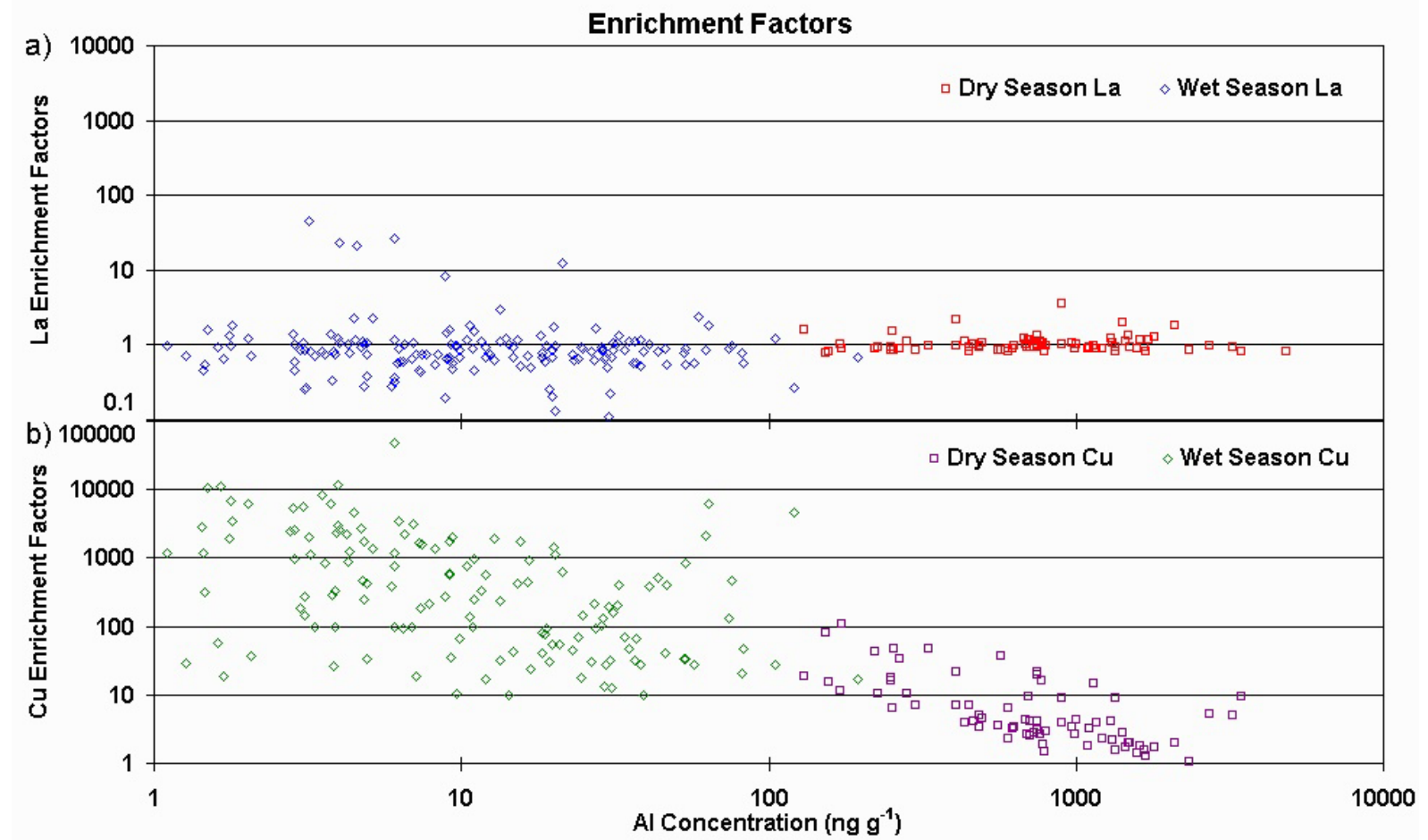

Fig. 6. Crustal enrichment factors and soil dust tracer concentration during dry (76 samples) and wet (190 samples) seasons for (a) La and (b) $\mathrm{Cu}$.

this adds another perspective for the relevance of wet season samples, with moisture coming from Amazon Basin to the East, as one considers evaluating the impact of remote sources to the site.

Considering wet season enrichments, one can distinguish at least three groups of elements:

(a) heavily enriched elements, with $E F>100: \mathrm{Cu}, \mathrm{Ag}$ (few samples), As, Sb, Zn, Cd, Mo, Co, Ni and Cr;

(b) moderately enriched elements, with $100<E F<10$ approximately: $\mathrm{Tl}, \mathrm{Na}, \mathrm{Pb}, \mathrm{P}, \mathrm{Ge}, \mathrm{Ca}, \mathrm{Li}, \mathrm{K}$ and $\mathrm{Ba}$;

(c) lightly enriched elements, with $E F<10$ : $\mathrm{Ta}, \mathrm{Nb}, \mathrm{Mg}$, Cs, Mn, Sr, Sc, V, Hf, Ce, U, Fe, Th, Pr, Sm, La, Rb, Nd, Ti, Lu, Ga, Yb, Y, Zr.

Heavily enriched elements are the most prone to originate from other sources than soil dust. Several elements in this group, like $\mathrm{Cu}$, As and $\mathrm{Cd}$ for example, are often associated with pollution sources generated by human economic activities. Hong et al. (1996) list Chile, to the Southwest of Illimani, as the world's largest $\mathrm{Cu}$ producer. Together with Peru to the North, the two countries (Fig. 1) are among the top 5 main producers of $\mathrm{Cu}$ today (Hong et al., 1996), which can explain this element's high average enrichment. In the group of moderately enriched elements one may have natural species that come from other sources than purely from soil dust, like $\mathrm{Na}$, Ca and Li (from salars). P and $\mathrm{K}$ are elements that take part in natural biogeochemical cycles in Amazonia, upwind from the site. $\mathrm{Zn}$ is also present in natural biogenic emissions, but the high enrichment factors observed suggest rather an anthropic influence. $\mathrm{Pb}$ frequently has anthropic origins, and a possible explanation for the observed enrichments could be mining activities at Chacaltaya to the North of Illimani or leaded automotive gasoline still in use in La Paz (R. Gallaire, personal communication, 2002). Elements with enrichments close to one, like $\mathrm{Fe}, \mathrm{La}$ and $\mathrm{Ti}$, are associated with the soil dust source, but clearly these values represent averages of all cases, so there may occur special situations where samples deviate from the mean value due to the influence of other sources.

\subsection{Characterization of regional soil dust aerosol}

In order to investigate the influence of different sources upon the measured elemental concentrations, one may examine the relationship between $E F$ and $\mathrm{Al}$ concentration, as shown in Fig. 6 for $\mathrm{La} \mathrm{(a)} \mathrm{and} \mathrm{Cu}$ (b). La is a rare-earth element originating from soil dust and with no known other sources in the region, while $\mathrm{Cu}$ may originate from mining activities. In Fig. 6a the $E F$ for La show a stable pattern around unity, for both dry and wet seasons, across four orders of magnitude of $\mathrm{Al}$ concentration. In other words, the measured $\mathrm{La} / \mathrm{Al}$ concentration ratios are near the average soil dust composition, 


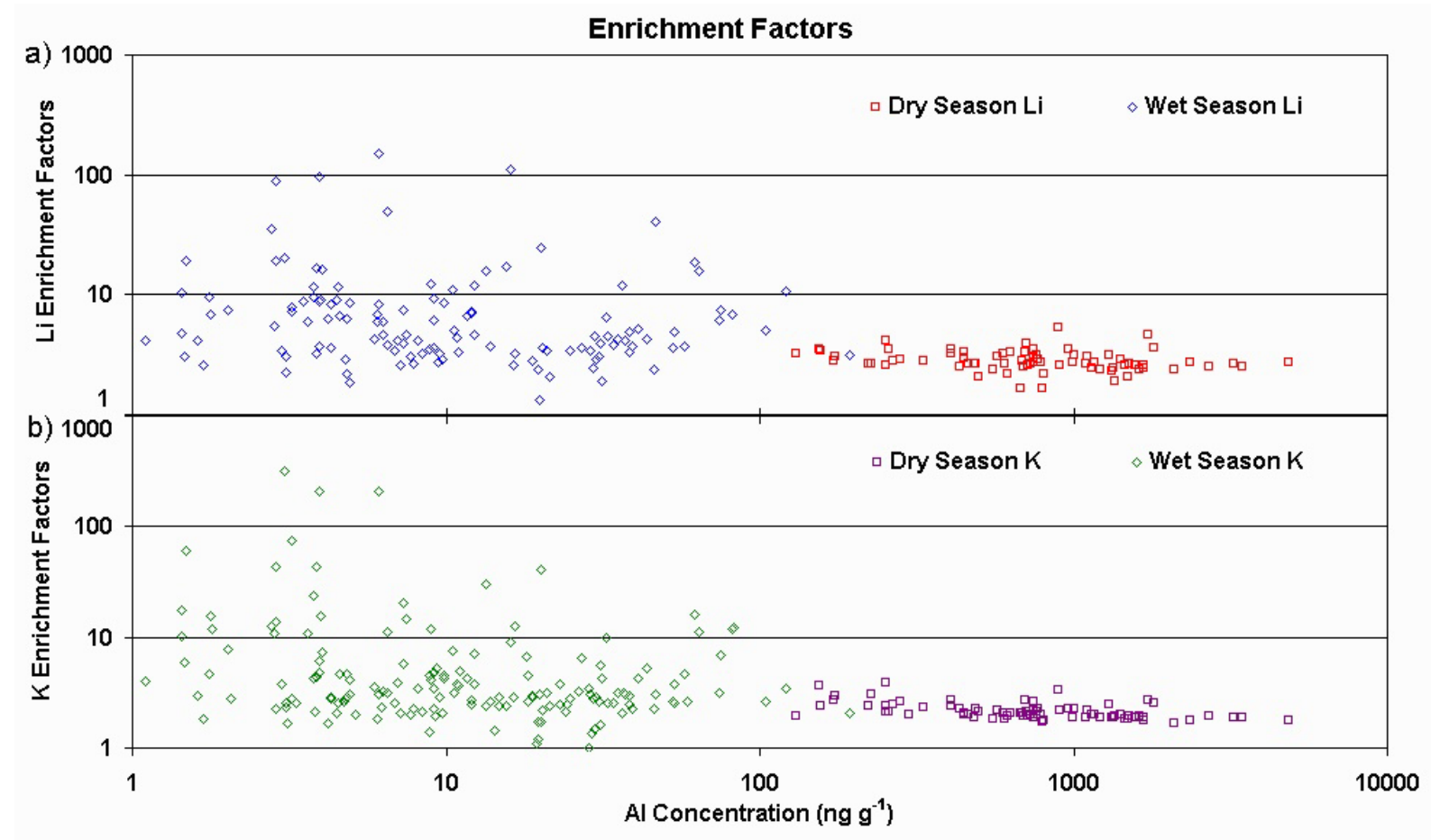

Fig. 7. Crustal enrichment factors and soil dust tracer concentration during dry (76 samples) and wet (190 samples) seasons for (a) Li and (b) $\mathrm{K}$.

irrespective of the soil dust tracer concentration. Wet season La $E F$ are noisier than the dry season's, but there are more wet season samples, so this may be a mere statistical fluctuation effect. In contrast, Fig. $6 \mathrm{~b}$ shows four orders of magnitude of $\mathrm{Cu}$ enrichment across the same range of $\mathrm{Al}$ concentrations. As the samples get more heavily loaded with aerosol (i.e. high $\mathrm{Al}$ concentration), $\mathrm{Cu} / \mathrm{Al}$ concentration ratios in dry and wet season samples tend toward mean soil dust values, as the regional aerosol outweighs the influence of other sources.

The pattern shown in Fig. $6 \mathrm{~b}$ is a clear indication of the existence of other sources, which grow in importance as the aerosol loading decreases in the samples. The same relationship between $E F$ and $\mathrm{Al}$ concentration was investigated for all other measured elements. Figure 7 shows the $E F$ across $\mathrm{Al}$ concentrations for $\mathrm{Li}$ and $\mathrm{K}$. As discussed before, possible sources for enriched $\mathrm{Li}$ are salars present in the region, while $\mathrm{K}$ has a variety of possibilities, among which include biomass burning products coming from the Amazon Basin. The patterns for Li and $\mathrm{K}$ in Fig. 7 lie intermediate between the ones for $\mathrm{La}$ and $\mathrm{Cu}$ shown in Fig. 6. Accordingly, they were classified as belonging to the moderately enriched elements in Fig. 5a, due to their average enrichment factors. For both $\mathrm{Li}$ and $\mathrm{K}$ in Fig. 7 the wet season samples show $E F$ value ranges of about two orders of magnitude, implying that most impact from remote aerosol sources occur during the summer season in the region. The biomass burning season in Amazon Basin corresponds to the dry season, when thick haze plumes leave the region yearly (Longo et al., 1999). This implies that the greatest $\mathrm{K} E F$ peaks during the wet season must come from other sources, as this element participates in biogeochemical cycles in Amazonia. Statistically, if any signal from biomass burning plumes during the dry season gets to Illimani, it must be at least partly obscured by the stronger winter regional aerosol source, which forces the $E F$ to their lowest values.

In Fig. 7 the lowest $E F$ during the dry season for both $\mathrm{Li}$ and $\mathrm{K}$ are clearly situated above one. As they form a plateau of $E F$ at high aerosol loadings (i.e. high $\mathrm{Al}$ concentrations), one may consider this ratio as the "true" (or effective) characteristic ratio for the precipitating aerosol at Illimani, which may be different from the mean soil composition ratio due to differences in the local soil composition and due to fractionation during aerosol mobilization. The hypothesis behind this assumption is that at the highest values of aerosol loadings the only source acting upon the site is the regional soil dust aerosol, and thus the conclusions drawn from it may be considered valid as long as this hypothesis holds.

Most measured elements show the plateau of $E F$ for high $\mathrm{Al}$ concentrations in the dry season. By studying in detail each element and plotting histograms of their $E F$, one can define the plateau levels as they peak in the lowest bins of the histograms. Figure 8 outlines this procedure for $\mathrm{Cd}$ enrichment factors during the dry season. This element shows 
Table 4. $E F$ plateaus, elemental ratios to $\mathrm{Al}\left(\times 10^{3}\right)$ in mean soil composition and in several measurements of Andean aerosols, compared to Illimani ice core background soil dust deposits

\begin{tabular}{|c|c|c|c|c|c|c|c|c|c|}
\hline \multirow[b]{3}{*}{ Element } & \multirow[b]{3}{*}{ EF plateau } & \multicolumn{8}{|c|}{ Elemental concentration ratios to $\mathrm{Al}\left(\times 10^{3}\right)$} \\
\hline & & \multirow[b]{2}{*}{ Mean soil ${ }^{a}$} & \multicolumn{6}{|c|}{ aerosols } & \multirow{2}{*}{$\begin{array}{l}\text { Illimani ice core } \\
\text { soil dust deposits }\end{array}$} \\
\hline & & & Chacaltaya $^{b}$ & Zongo $^{b}$ & Patacamaya $^{b}$ & Chacaltaya $^{c}$ & Chacaltaya $^{d}$ & Atacama $^{e}$ & \\
\hline $\mathrm{Li}$ & 2.62 & 0.352 & & & & & & & 0.924 \\
\hline $\mathrm{Na}$ & 3.51 & 70.4 & & & & 240 & 139 & & 247 \\
\hline $\mathrm{Mg}$ & 1.81 & 70.4 & & & & 110 & 139 & & 128 \\
\hline $\mathrm{Al}$ & 1.00 & 1000 & 1000 & 1000 & 1000 & 1000 & 1000 & 1000 & 1000 \\
\hline $\mathrm{P}$ & $1.49^{g}$ & 11.3 & & & & & & & 16.7 \\
\hline $\mathrm{K}$ & 1.84 & 197 & 210 & $1790^{b}$ & 140 & 310 & 178 & 440 & 363 \\
\hline $\mathrm{Ca}$ & 0.991 & 211 & 170 & 210 & 200 & 330 & 151 & 480 & 209 \\
\hline Sc & $1.52^{g}$ & 0.0986 & & & & 0.17 & 0.17 & & 0.150 \\
\hline $\mathrm{Ti}$ & 0.897 & 70.4 & 40 & 30 & 30 & 61 & 36 & 90 & 63.2 \\
\hline $\mathrm{V}$ & 1.03 & 1.27 & & & & 1 & 1.3 & & 1.31 \\
\hline $\mathrm{Cr}$ & 0.704 & 0.986 & & & & 2.4 & 1.43 & & 0.694 \\
\hline $\mathrm{Mn}$ & 0.697 & 14.1 & & & & 10 & 6.7 & 30 & 9.82 \\
\hline $\mathrm{Fe}$ & 0.848 & 563 & 530 & 320 & 280 & 710 & 394 & 780 & 478 \\
\hline Co & 1.81 & 0.113 & & & & 4 & 0.43 & & 0.204 \\
\hline $\mathrm{Ni}$ & 0.261 & 0.704 & & & & 2 & 0.51 & & 0.184 \\
\hline $\mathrm{Cu}$ & $1.77^{g}$ & 0.423 & & & & 5 & & 10 & 0.748 \\
\hline $\mathrm{Zn}$ & $1.31^{g}$ & 1.27 & & & & 17 & & 8 & 1.66 \\
\hline $\mathrm{Ga}$ & 0.935 & 0.282 & & & & & 0.19 & & 0.263 \\
\hline $\mathrm{Ge}$ & 1.76 & 0.0141 & & & & & & & 0.0248 \\
\hline As & 9.95 & 0.0845 & & & & 6.4 & & 7 & 0.841 \\
\hline $\mathrm{Rb}$ & 0.870 & 2.11 & & & & & 1.4 & 6 & 1.84 \\
\hline $\mathrm{Sr}$ & 1.33 & 3.52 & & & & & 2.58 & 10 & 4.69 \\
\hline $\mathrm{Y}$ & 0.524 & 0.563 & & & & & & & 0.295 \\
\hline $\mathrm{Zr}$ & 0.259 & 5.63 & & & & & & & 1.46 \\
\hline $\mathrm{Nb}$ & $1.51^{g}$ & 0.141 & & & & & & & 0.212 \\
\hline Mo & 1.99 & 0.0169 & & & & & & & 0.0337 \\
\hline $\mathrm{Ag}$ & $4.13^{g, h}$ & 0.000704 & & & & & & & 0.00291 \\
\hline $\mathrm{Cd}$ & 1.97 & 0.00493 & & & & 4 & & & 0.00973 \\
\hline $\mathrm{Sb}$ & $6.36^{g}$ & 0.0141 & & & & 3.4 & & & 0.0896 \\
\hline $\mathrm{Cs}$ & 4.03 & 0.0563 & & & & 0.3 & 0.29 & & 0.227 \\
\hline $\mathrm{Ba}$ & 1.53 & 7.04 & & & & & 6.3 & & 10.8 \\
\hline $\mathrm{La}$ & 0.936 & 0.56 & & & & 0.6 & 1.3 & & 0.527 \\
\hline $\mathrm{Ce}$ & 1.53 & 0.704 & & & & & 1.4 & & 1.08 \\
\hline $\operatorname{Pr}$ & 1.26 & 0.0986 & & & & & & & 0.125 \\
\hline $\mathrm{Nd}$ & 0.883 & 0.493 & & & & & & & 0.435 \\
\hline $\mathrm{Sm}$ & 1.37 & 0.0634 & & & & 0.11 & 0.096 & & 0.0869 \\
\hline $\mathrm{Yb}$ & 0.626 & 0.0423 & & & & & & & 0.0264 \\
\hline $\mathrm{Lu}$ & 0.708 & 0.00563 & & & & & 0.007 & & 0.00399 \\
\hline $\mathrm{Hf}$ & $0.700^{g}$ & 0.0845 & & & & & & & 0.0591 \\
\hline $\mathrm{Ta}$ & 0.613 & 0.0282 & & & & & & & 0.0173 \\
\hline $\mathrm{Tl}$ & 4.48 & 0.00282 & & & & & & & 0.0126 \\
\hline $\mathrm{Pb}$ & $1.95^{g}$ & 0.493 & & & & 21 & & 9 & 0.963 \\
\hline Th & 1.34 & 0.127 & & & & 0.2 & 0.19 & & 0.170 \\
\hline $\mathrm{U}$ & 1.51 & 0.0282 & & & & & & & 0.0424 \\
\hline
\end{tabular}

${ }^{a}$ Bowen, 1979; ${ }^{b}$ Lawson and Winchester, 1979. 2-4 samples by site (all in Bolivia), from July 1976-March 1977, aerosol particles above $4 \mu \mathrm{m}$. K at Zongo from biogenic origin; ${ }^{c}$ Adams et al., 1977. All aerosol particle sizes; ${ }^{d}$ Adams et al., 1980. All aerosol particle sizes, samples from July $1975-A u g u s t ~ 1977 ;^{e}$ Rojas et al., 1990. 34 samples from Northern Atacama desert, Chile; ${ }^{f}$ this work; ${ }^{g}$ elements that do not form a clear $E F$ plateau; ${ }^{h}$ few samples. 


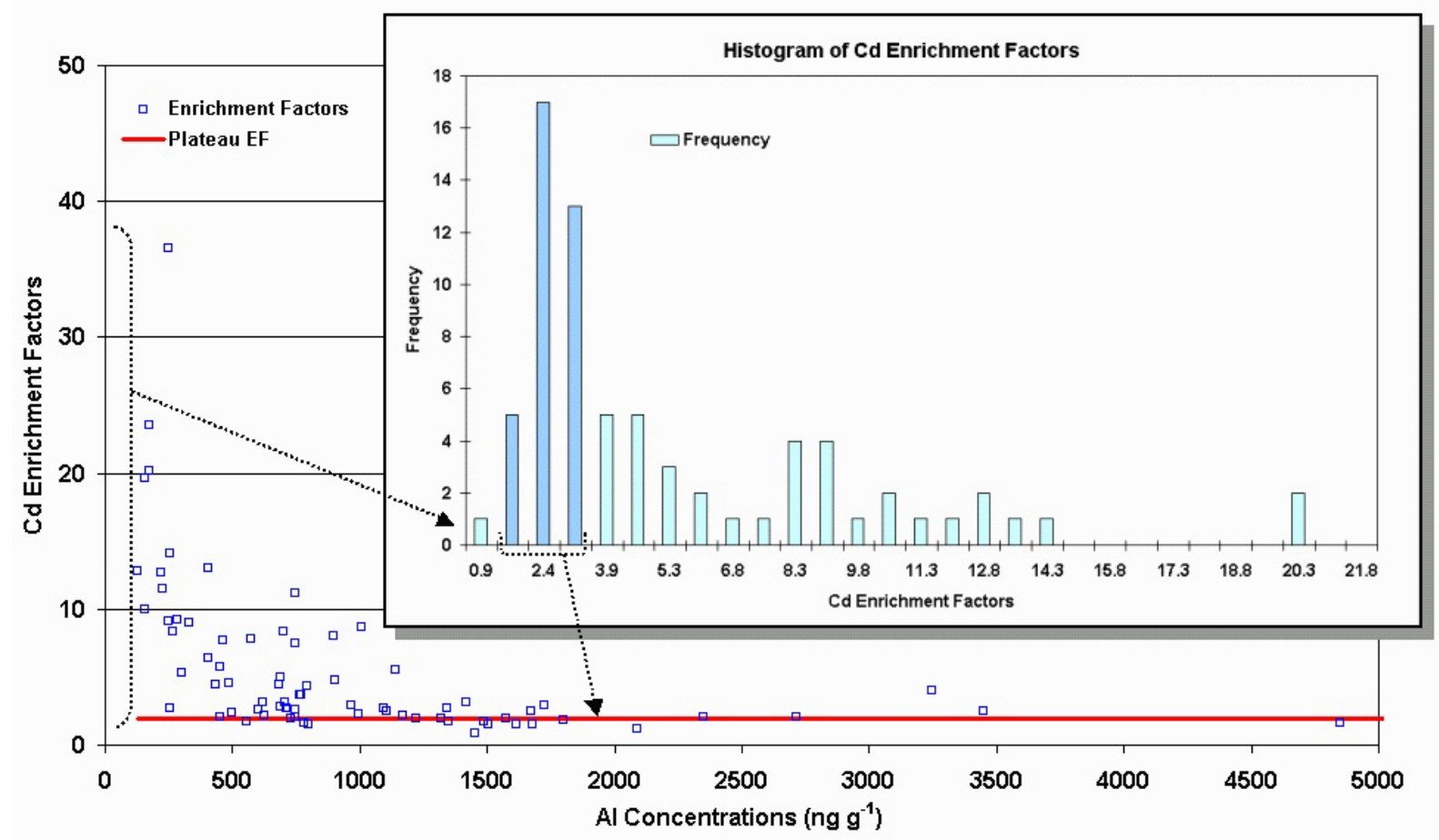

Fig. 8. Dry season $\mathrm{Cd}$ enrichment factors and Al concentration. On the inset, the peak in the histogram corresponds to the plateau denoted by the horizontal red line.

a clear $E F$ plateau as one moves towards high $\mathrm{Al}$ concentrations. Using different bin steps for histograms of its $E F$, as illustrated on the inset of Fig. 8, one gets the lowest peak by 1.97 , and this can be defined as the plateau $E F$ for $\mathrm{Cd}$, as shown by the red horizontal line in Fig. 8. This process can be repeated for all measured elements, although some of them may be ill posed, as they do not form a clear plateau level. In these cases the level found may be considered tentative, as a first approximation.

With these $E F$ plateau levels for all elements one may proceed with a renormalization of the reference source elemental ratios, i.e., to calculate the effective characteristic ratios that give unitary $E F$ for samples at the plateau, as they represent the regional soil dust aerosol source deposited at Illimani. Table 4 summarizes these results for all measured elements with three significant figures, showing the calculated $E F$ plateau levels, the elemental concentration ratios to $\mathrm{Al}$ in the original soil composition source by Bowen (1979), several measurements of aerosol elemental concentrations ratios in Andean sites (Lawson and Winchester, 1979; Adams et al., 1977; Adams et al., 1980; Rojas et al., 1990), and also the values of elemental ratios to $\mathrm{Al}$, calculated by the procedure depicted above for characterizing the soil dust aerosol deposited in Illimani ice core.

Most elements present $E F$ plateau levels within a factor of two above or below the mean soil composition, with exceptions of high $E F$ like As (9.95), $\mathrm{Na}$ (3.51) and $\mathrm{Li}$ (2.62), but also with low $E F$ plateaus like $\mathrm{Ni}(0.261)$ and $\mathrm{Zr}(0.259)$. These departures reflect local differences of soil composition and also fractionation occurring during aerosol production, as discussed before, but one has to consider they may also arise in part due to local $\mathrm{Al}$ concentration divergences from the reference source: since this element was chosen as soil dust tracer it is the only parameter held constant, so any eventual fluctuations will influence the $E F$ calculated for the other elements. At any rate, the identification of $E F$ plateau levels is based on a statistical approach performed over a confined universe of samples during the 20th century, which may embed background levels of anthropic soil pollution. For instance, Ferrari et al. (2001) suggest the existence of significant anthropogenic emissions of heavy metals even before the 20th century (Table 3 ). The aerosol characterization, based on elemental ratios to $\mathrm{Al}$ shown in Table 4, corresponds to the effective content of background soil dust aerosol for the 20th century as trapped by snow, irrespective of other factors like "true" soil composition or fractionation during mobilization.

In Table 4, comparing the elemental ratios to $\mathrm{Al}$ determined on Andean aerosol samples and the ratios on Illimani soil dust aerosol determined by the plateau method, remarkable matches arise for several elements: $\mathrm{Na}, \mathrm{Mg}, \mathrm{K}, \mathrm{Ca}, \mathrm{Sc}$, $\mathrm{Ti}, \mathrm{V}, \mathrm{Mn}, \mathrm{Fe}, \mathrm{Ga}, \mathrm{Rb}, \mathrm{Cs}, \mathrm{La}, \mathrm{Ce}, \mathrm{Sm}$ and Th are present both in the Andean aerosol determinations as well as in Illimani soil dust at about the same proportion to Al. These elements 
are most likely related to natural soil dust produced regionally. However, as atmospheric aerosols correspond to a mixture of several natural and anthropic sources, one does not expect identical concentration ratios to $\mathrm{Al}$ for all elements present in aerosol samples and at Illimani soil dust. In fact, anthropogenic pollution-related elements present higher concentration ratios to $\mathrm{Al}$ in atmospheric aerosols than at soil dust derived from Illimani: $\mathrm{Cr}, \mathrm{Co}, \mathrm{Ni}, \mathrm{Cu}, \mathrm{Zn}, \mathrm{As}, \mathrm{Cd}, \mathrm{Sb}$ and $\mathrm{Pb}$. Notice, in particular, the high ratios for $\mathrm{Cu} / \mathrm{Al}$ in Chile (Atacama) and $\mathrm{Pb} / \mathrm{Al}$ in Bolivia (Chacaltaya), due to anthropogenic activities in the region. Almost all measured elements at Atacama desert by Rojas et al. (1990), except for $\mathrm{Pb}$ and $\mathrm{Zn}$, present higher concentrations relative to $\mathrm{Al}$ than Bolivian determinations, due to the existence of a significant source of heavy metals in Chile linked to $\mathrm{Cu}$ production (Hong et al., 1996).

\section{Conclusions}

The measurement of concentrations for 45 elements in Illimani ice core by ICP-MS continuously during the 20th century allowed studying elemental profiles at high temporal, mostly sub-seasonal, resolution. With seasonal segregation of samples thus made possible, one observes during dry austral winter high elemental concentrations and low crustal enrichment factors. During this dry season regime, remote sources get obscured by regional soil dust aerosol, which may render difficult the identification of aerosol sources like biomass burning from the Amazon Basin. The regional Illimani soil dust aerosol is more easily produced during dry winter in comparison to wet season conditions due to diminishing of wet deposition removal processes and parallel enhancement of soil dryness. For wet austral summer the situation is the opposite, with low elemental concentrations and samples often showing high crustal enrichment factors. During the wet season, aerosol deposition processes limit the impact of regional soil dust aerosol, allowing the identification of elements with high crustal enrichments associated with anthropic sources, as well as moderately enriched elements from other possible sources of long-range transported aerosol (e.g. salars, Amazonia).

The stable isotopic record, also analyzed under the seasonal segregation scheme, indicates a warming of wintertime average temperatures after the 1970 s, but with no clear trend for summer. The elemental concentrations record for wet seasons show a degree of modulation together with the stable isotopic record, as long-term, multi-year intervals. In these intervals most isotopic depleted years correspond to greatest amounts of precipitation and consequently to lowest recorded elemental concentrations.

Comparison of Illimani record to a few samples from another ice core in the Andes (Sajama, Western Bolivian Andes), shows that the ranges of average elemental concentrations between dry and wet seasons at Illimani correspond in general to the values at Sajama. Differences arise mostly for species of anthropic origin, as indicated in Table 3, and are related to the proximity of Illimani to significant local sources. Mining-related species are more enriched at Illimani than Sajama even in the beginning of 20th century.

A detailed chemical characterization for the background soil dust aerosol deposited in the Andes was derived. This effective characterization, shown in Table 4 as concentration ratios to aluminum, was only made possible by following a research paradigm focused on the statistical robustness of elemental concentration measurements, performed over Illimani samples covering 80 years during 20 th century.

Acknowledgements. A. Correia thanks the IRD fieldwork team for extraction and transportation of the ice cores, the LGGE personnel for fully supporting this work, Dr. Michel Valladon from LMTG for making lab work possible for all those 744 samples and E. Ramirez from LSCE for measurements of stable isotopes content. This work was supported by CNPq grant 142.683/98-1 and CAPES grant BEX 0458/99-6. Ice core drilling expedition photos by Bernard Pouyaud.

\section{References}

Adams, F., Dams, R., Guzman, L., and Winchester, J. W.: Background aerosol composition on Chacaltaya mountain, Bolivia, Atm. Env., 11, 629-634, 1977.

Adams, F., Van Craen, M., Van Espen, P., and Andreuzzi, D.: The elemental composition of atmospheric aerosol particles at Chacaltaya, Bolivia, Atm. Env., 14, 879-893, 1980.

Bowen, H. J. M.: Environmental Chemistry of the Elements, Academic Press, London, 1979.

Clausen, H. B. and Langway Jr., C. C.: The ionic deposits in polar ice cores, in: The Environmental Record in Glaciers and Ice Sheets, Oeschger, H. and Langway Jr., C. C. (Eds), John Wiley and Sons, 225-247 1989.

De Angelis, M., Bonnaveira, H., Taupin, J.-D., Correia, A., Ramirez, E., and Delmas, R. J.: Aerosol chemistry (major ions) in the Bolivian Andes from the Illimani ice core, Atm. Chem. Phys., in preparation, 2003a.

De Angelis, M., Simões, J. C., Bonnaveira, H., Taupin, J.-D., and Delmas, R. J.: Volcanic eruptions recorded in the Illimani ice core (Bolivia): 1918-98 and Tambora periods, Atm. Chem. Phys. Discuss., 3, 2427-2463, 2003 b.

Delmas, R. J.: Environmental information from ice cores, Rev. Geophys., 30, 1-21, 1992.

Ferrari, C. P., Clotteau, T., Thompson, L. G., Barbante, C., Cozzi, G., Cescon, P., Hong, S., Maurice-Bourgoin, L., Francou, B., and Boutron, C. F.: Heavy metals in ancient tropical ice: initial results, Atm. Env., 35, 5809-5815, 2001.

Freydier, R.: Chimie des précipitations en Afrique intertropicale: anions et cations majeurs, éléments traces et acides organiques, Ph.D. Thesis, Université Paul Sabatier, Toulouse, 1997.

Freydier, R., Dupré, B., and Lacaux, J. P.: Precipitation chemistry in Intertropical Africa, Atm. Env., 32, 749-765, 1998.

Grootes, P. M., Stuiver, M., Thompson, L. G., and MosleyThompson, E.: Oxygen isotope changes in tropical ice, Quelccaya, Peru, J. Geophys. Res., 94, 1187-1194, 1989. 
Hong, S., Candelone, J.-P., Soutif, M., and Boutron, C. F.: A reconstruction of changes in copper production and copper emissions to the atmosphere during the past 7000 years, Sci. Total Env., 188, 183-193, 1996.

Jakubowski, N., Feldmann, I., and Stuewer, D.: Analytical improvement of pneumatic nebulization in ICP-MS by desolvation, Spectrochim. Acta, 47B, 107-118, 1992.

Lawson, D. R. and Winchester, J. W.: A standard crustal aerosol as a reference for elemental enrichment factors, Atm. Env., 13, 925-930, 1979.

Longo, K. M., Thompson, A. M., Kirchhoff, V. W. J. H., Remer, L. A., de Freitas, S. R., Dias, M. A. F. S., Artaxo, P., Hart, W., Spinhirne, J. D., and Yamasoe, M. A.: Correlation between smoke and tropospheric ozone concentration in Cuiabà during Smoke, Clouds, and Radiation-Brazil (SCAR-B), J. Geophys. Res., 104, 12 113-12 129, 1999.

Lorius, C., Raisbeck, G., Jouzel, J., and Raynaud, D.: Long-term environmental records from Antarctic ice cores, in The Environmental Record in Glaciers and Ice Sheets, Oeschger, H. and Langway Jr., C.C. (Eds), John Wiley and Sons, 343-361, 1989.

Ramirez, E., Hofmann, G., Taupin, J.-D., Francou, B., Ribstein, P., Caillon, N., Ferron, F. A., Landais, A., Petit, J.-R., Pouyaud, B., Schotterer, U., Simões, J. C., and Stievenard, M.: A new Andean deep ice core from Nevado Illimani (6350 m), Bolivia, Earth. Plan. Sci. Let., 212, 337-350, 2003.

Risacher, F.: Géochimie des lacs salés et croûtes de sel de l'Altiplano Bolivien, Sci. Géol., Bull., 45, 3-4, 135-214, 1992.

Rojas, C. M., Figueroa, L., Janssens, K. H., Van Espen, P. E., Adams, F. C., and Van Grieken, R. E.: The elemental composition of airborne particulate matter in the Atacama desert, Chile, Sci. Total Env., 91, 251-267, 1990.

Sholkovitz, E., Church, T. M., and Arimoto, R.: Rare earth element composition of precipitation particles and aerosols, J. Geophys. Res., 98, 20 587-20 599, 1993.
Simões, J. C., Taupin, J.-D., Ribstein, P., Petit, J.-R., De Angelis, M., Ramirez, E., Hoffmann, G., Correia, A., Delmas, R. J., Dupré, B., Ginot, P., and Francou, B.: Forty years of environmental record from the Nevado Illimani ice core, Central-Eastern Andes, J. Geophys. Res., in preparation, 2003.

Thompson, L. G., Mosley-Thompson, E., Bolzan, J. F., and Koci, B. R.: A 1500-Year Record of Tropical Precipitation in Ice Cores from the Quelccaya Ice Cap, Peru, Science, 229, 971-973, 1985.

Thompson, L. G., Davis, M. E., Mosley-Thompson, E., Sowers, T. A., Henderson, K. A., Zagorodnov, V. S., Lin, P.-N., Mikhalenko, V. N., Campen, R. K., Bolzan, J. F., Cole-Dai, J., and Francou, B.: A 25000 -Year Tropical Climate History from Bolivian Ice Cores, Science, 282, 1858-1864, 1998.

Thompson, L. G.: Ice core evidence for climate change in the Tropics: implications for our future, Quat. Sci. Rev., 19, 19-35, 2000.

Vuille, M.: Atmospheric circulation over the Bolivian Altiplano during dry and wet periods and extreme phases of the Southern Oscillation, Int. J. Climatol., 19, 1579-1600, 1999.

Vuille, M., Bradley, R. S., and Keimig, F.: Interannual climate variability in the Central Andes and its relation to tropical Pacific and Atlantic forcing, J. Geophys. Res., 105, 12 447-12 460, 2000.

Wagenbach, D.: Environmental records in Alpine glaciers, in The Environmental Record in Glaciers and Ice Sheets, Oeschger, H. and Langway Jr., C.C. (Eds), John Wiley and Sons, 69-83, 1989.

Wolff, E. and Peel, D.: The record of global pollution in polar snow and ice, Nature, 313, 535-540, 1985.

Wolff, E. W., Suttie, E. D., and Peel, D. A.: Antarctic snow record of cadmium, copper, and zinc content during the twentieth century, Atm. Env., 33, 1535-1541, 1999. 